\title{
Integrated Systems in the Role of Integration of Education
}

\author{
Katalin TERNAI \\ Budapest University of Economic Sciences and Public Administration \\ Department of Information Systems \\ Veres Palne u. 36, H-1053 Budapest, Hungary \\ e-mail:ternai@informatika.bke.hu
}

Received: June 2003

\begin{abstract}
Information society paradigm and program highly affect the higher education as well. The rapidly changing environment reflects both the contents and the organisation. The effects are significant concerning the ICT related departments and disciplines, but the IT technology can change very traditional subjects as philosophy radically. An interesting symptom of the alwaysconservative academic world: the organizational structure of the universities is very hierarchical, the knowledge transfer (what we call education) is fragmented, atomised. On the other way around the real world requirements are just the opposites: there is a vast demand for students and professionals having the ability of integration, knowledge absorption. The general tendencies look a little bit more sharpened in the world of transition, in both the economic and social sense. During the last ten years Hungary went through an intensive development and changing phase in which the experiences of transition and coping with the information society requirements mixed up. In our paper we are going to illustrate a way to develop the teaching in the higher education on an integrated ERP platform.
\end{abstract}

Key words: integrated system, integration of education, enterprisewide computing, Enterprise Resources Planning, ERP II, Excellence Center.

\section{Theoretical Background}

An enterprise's success is directly related to the speed with which it can respond to changes in its business environment and create value for its chosen market space. It is almost impossible today to run a competitive business without a computerized information system (Redman, 1998). The rapidly increased use of the web, the electronic commerce (EC) change the manner in which business is done in almost all organizations (Lederer, 1998). Computer-based information systems in conjunction with EC applications are enhancing competitiveness and creating strategic advantage to organizations (Porter, 1985).

Providing a computerized solution to a business problem may require integrating a lot of information systems. ERP (Enterprise Resources Planning) systems are one of the most popular enterprise applications, and present a new model of enterprisewide computing. They allow companies to replace their legacy systems with a single, integrated system, in which it is possible to plan and manage the use of the resources of an entire enterprise. 
The main benefits are the increased efficiency, the improved quality, productivity, and profitability (for more issues, see Parker, 1989; Davenport, 1998; 2000; Koch, 1999).

ERP systems cover the core activities of the firm (e.g., accounting, finance, manufacturing, human resources). In these traditional functional areas repetitive tasks exist that are essential to the operation of the organization such as billing a customer, preparing a payroll. ERP solutions are centered around business transactions. The information system that automates manual computations is called the transaction processing system (TPS) (see Claybrook, 1992; Subrahmanyam, 1999).

The more powerful ERP developments improve decision making. These systems support access, organize, summarize and display information for repetitive decision making and managers in the functional areas. Such applications are called functional management information systems (MIS). Details can be found in (Koory, 1987; McLeod, 1990).

Some ERP systems also support office workers (office automation system - OAS), people working in groups in different locations (group support system - GSS), robotics and computer-aided design and manufacturing (CAD/CAM) (Palaniswamy, 2000).

Most ERP vendors add business intelligence functionalities to their applications. Computerized support to complex, nonroutine decision (decision support system - DSS) and all managers in the enterprise (executive information system - EIS) are built into these systems (see Dutta, 1997; Turban, 1990).

The new generation of ERP systems are the ERP II systems - the integration of ERP, customer relationship management (CRM), knowledge management (KM) and data warehousing (DW) and mining (DM) with e-commerce. This is of a great importance. In this new model e-commerce not only refers to buying and selling, but is also about enhanced productivity, reaching new customers, and sharing knowledge across institutions for competitive advantage (for more information, see Nonaka, 1995; Davenport and Prusak, 1998; Gray, 2001).

To handle such a large and complex application ERP vendors started to break up their systems into individual components. Componentization helps the vendors to enhance their solutions and the customers to customize and upgrade the software (Johnson, 2000).

\section{The Initial Project}

On the 10th of November 1997 BUES (Budapest University of Economic Sciences) drew a contract with SAP AG. Under the frame of the co-operation agreement SAP offered R/3 system for the university, hardware partners helped us with workstations (HewlettPackard) and server (DEC).

The main goal of our project was to provide a coherent and consistent background to the several departments to integrate the education and the knowledge.

We also declared these objectives:

- to examine how can change IT the traditional subjects in the higher education;

- to develop the atomised teaching on an integrated ERP platform; 
- to work out the most appropriate method of teaching on this special framework;

- to develop and improve new courses, executive programs;

- to supply integrated education in co-operation with other (not only Hungarian) universities as well;

- to transfer the built-in æbest practiciesÆ from the ERP systems to the academic enviroment.

It is well known how the $\mathrm{R} / 3$ is composed, for university teaching purposes not only the implementation but also the complex business reference model proved useful. This knowledge can be transferred to the academic environment, it could confront with theories. The complexity and the integrity of the system, makes the SAP capable of helping the education in every field of the corporate management. Students get familiar with the state-of-the art information technology, architecture and business solution. SAP establishes the opportunity for students to enrich and enlarge their knowledge-acquainted during lectures - in practical seminars. It also allows them to conduct practical experiments in different economy related fields. The application of modern techniques, technologies and theories, the continuous development of the system raises SAP to one of the leaders of the corporate information system market. In accordance with it, another advantage of applying SAP in education is, that as a consequence of software upgrading, the contents of subjects - taught at the university - also have to be updated, therefore they are more likely to keep up with the newest achievements. As the result of the synthesis of theoretical and practical education, SAP raises the education indisputably to a higher level.

Nevertheless, the advantage of using an advanced information system is inevitable. We found an even more important advantage of implementing an integrated system behind the formal academic teaching. It is widely known that the departmental organisation of teaching is fairly atomised. Controlling professor teaches controlling, accounting professor accounting, .... The students learn different terminology, different concepts, they got different practical assignment. There is always a risk, weather they see the interconnections among production management, accounting, controlling and many other aspects of the management. Without any sever interference with the departments we launched an in-house program in the early 98 , how to get familiar with $R / 3$, how to employ the system or rather one module of the system in the formal education program. After the first burst of enthusiasm Department of Management, Business Economics, Finance and Information Systems continued the joint project. The overall goal was to provide a coherent and consistent background to the several departments for practical assignments. If the curricula are different the practical assignments will help the students to integrate the knowledge (Fig. 1).

It was also an issue to be investigated what type of practical assignment would serve the educational purposes best. After several discussions a three-layered conclusion was unison accepted:

- demonstration;

- problem solving application;

- major case study. 


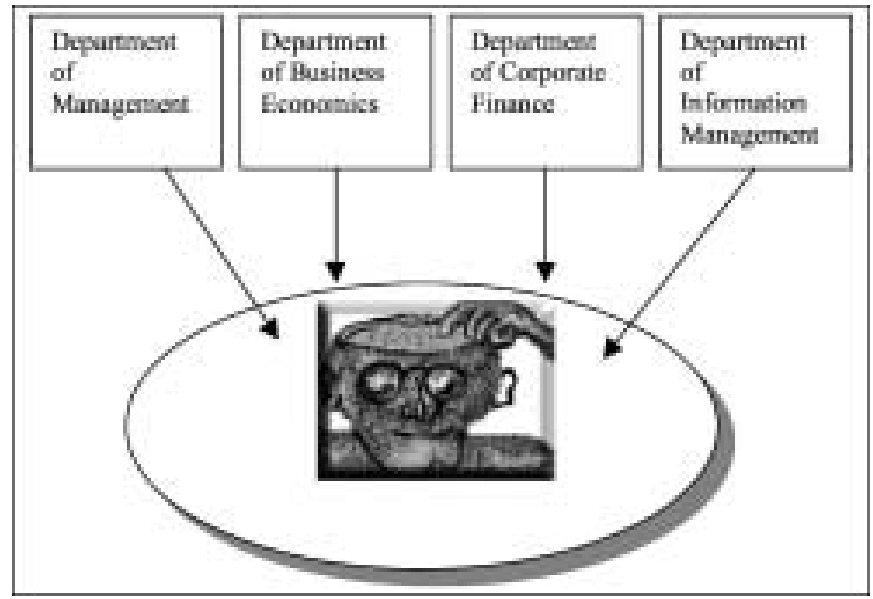

Fig. 1. An integrated system provides a common platform to integrate the education.

Demonstration aims mainly illustration. The students' participation is passive, the teacher shows/demonstrates functions - in a fully operational environment. It is tricky, sometimes the explanation of the environment is longer and more complicated than the illustrated function itself. Therefore it assumes well-trained teachers, and effective support.

Problem solving application: smaller assignments to the students, but the students work independently and actively. Part of the course is in-group, part of it needs individual efforts. Students usually apply their knowledge and it is not a goal to modify or develop the system.

Major case studies usually lead to the thesis work and they can be equivalent with an elective subject as well. There are a big variety of topics, as quality management, workflow management, ABC (activity based costing). A deeper understanding of the system is assumed and the creative application is a core requirement. Implementing a case study also goes with a major help of the system administrator. It is the responsibility of the departments to assign any kind of assignment, the only "plus" is a slight horizontal coordination.

We already have the experiences of six years. Courses are being held on controlling, corporate finance, information management, material management, and recently we have introduced the public administration treasury module as well. The feedback from the students is favourable, they like the idea to learn different subjects in the same environment (not mentioning the fact, that they learn only once how to navigate in the system and they can use that "many" times.)

\section{Enhancing the Project}

The advantages of the co-operation are indisputable. The real added value comes from the opportunity of development of new courses. The already running courses can be up- 


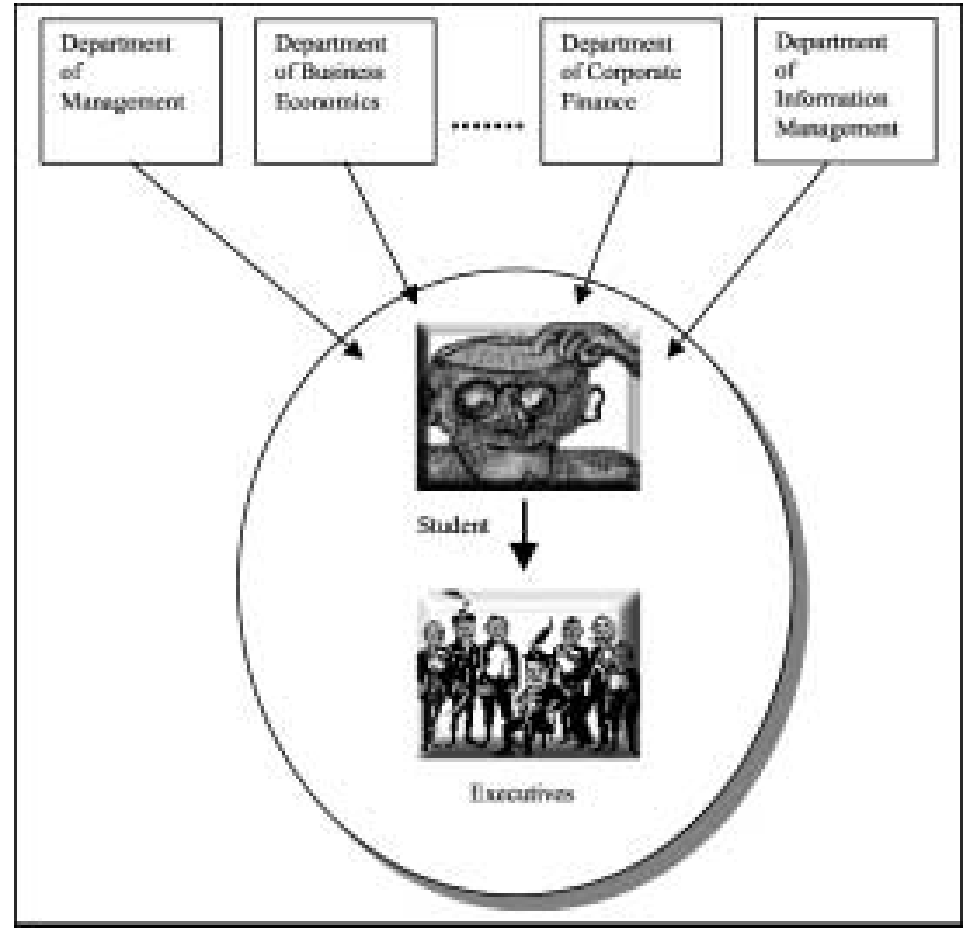

Fig. 2. The added value comes from the opportunity of development of new courses.

graded from the process-oriented view to the more complex problem-solving view (as happened in the case of Controlling, which had been totally reworked due to the available practical background or Corporate Finance). Also new areas were investigated, IT audit in first place, which is a nice and interesting combination of management accounting, controlling, information technology and information management. The other new feature of the development is a real executive program (Fig. 2).

The program is vendor-independent, (although it may sound strange) and the focus is on providing knowledge on finance, accounting, controlling and information management in order to facilitate executives (the students) to give a solid foundation of their decisions. The Information Manager postgraduate course has already been running for four years.

\section{Interorganizational Roll-Out}

The next step further should be (and that is already taking place), that this common platform ought to supply integrated education not only in co-operation with the different departments, but with other universities as well. The experience, gathered during the years, gives the basis of the extension of the system and the number of users, which is finally embodied in the form of a BUES-SAP Excellence Center in August of 1999 (Fig. 3). 


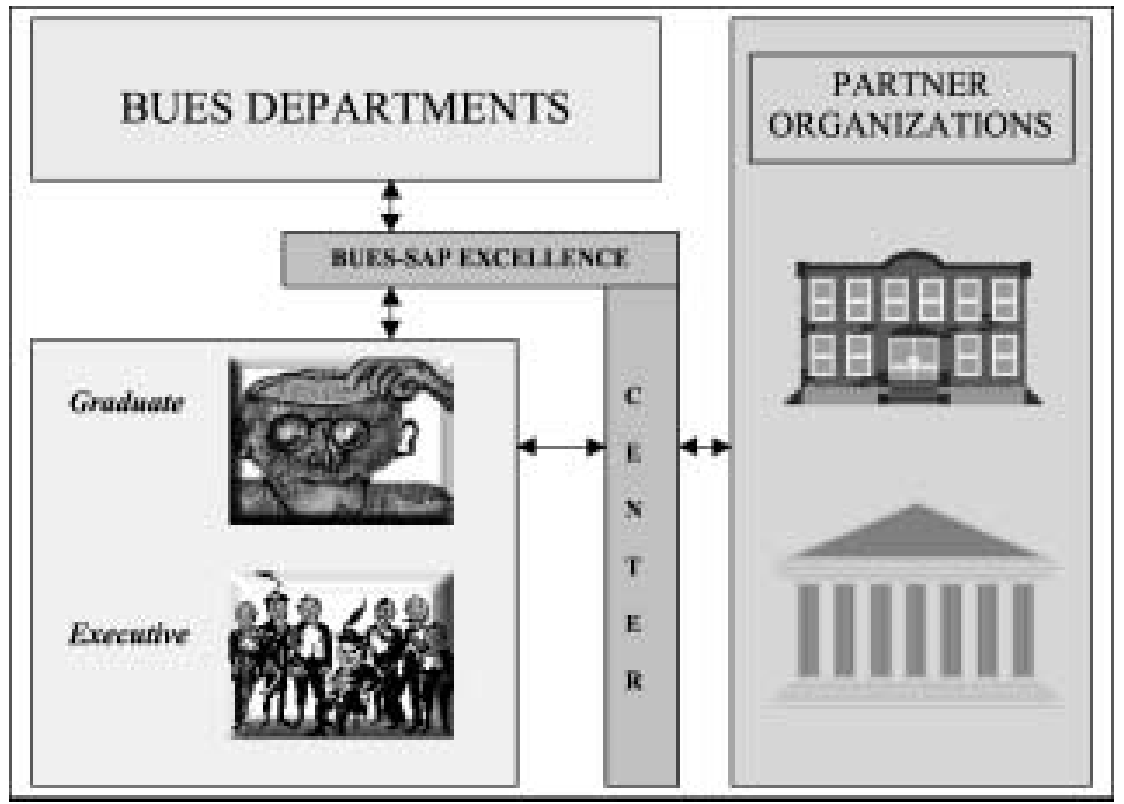

Fig. 3. The BUES-SAP Excellence Center.

\section{Main Taskgroups of the Excellence Center}

1. Implementation and maintenance of the modules of SAP R/3 system.

2. Educational support:

- design and operate the "Teach-the-Teacher" program. The courses prepare the applicant teachers to be able to insert the SAP modules into the curriculum of their academic course. In the first period the program consists of a few one-day intro-courses, later three-day standard-courses per modules;

- invitation and co-ordination of SAP thesis topics. Providing and organising continuous consultation;

- composing curriculum and/or establishing connection to existing curriculum, that are needed for self-training and help deepening SAP knowledge.

3. Establishing the Higher Education Club (HEC)

- organisation workshops with invited guests;

- oorganisation of conferences in order to demonstrate results, discuss experiences.

\section{Help Desk}

- design and implementation of Help Desk functions in Lotus Notes;

- access of WEB services for entitled users.

5. User and system administration. 
Officially the Excellence Center was announced on 27th of August 1999, during the biggest IT conference in higher education in Debrecen. Professionals, responsible for IT education got acquainted with the Excellence Center idea and services, and from that moment they could join an open platform for co-operation. Technical universities, colleges, (the actual number of the participants is more than ten) agreed in joint development of curricula, joint development and exchange of teaching material, also in joint teaching activities. The latter mentioned is a great challenge itself, since the combination of a web based technology with a web based on line teaching is not a trivial task. Some details come in the later parts of this paper.

For the time being IDES 4.5B version is in use. The IDES is an already installed and parameterised training system. The overall structure of the systems follows the hierarchy and collaborating structure of the Center:

- 000 and 001 (for country specific) mandant;

- 800 and 801 IDES mandant;

- 900 BUES mandant;

- from 901 to 919 "educational mandant" for partners;

- 920 common IDES "demo mandant";

- default pilot SAP mandant.

Of course, on one hand every university would like to have its own system. On the other hand the maintenance and administration of a complete system is very costly. Therefore the partners like the idea of the virtual university SAP center. They can save money, while through the academic network they reach the server and many of the services (help desk, promotion campaign, upgrades, not talking about the advantages of knowledge sharing).

It is important to mention that the interorganizational co-operation cannot be restricted to the Hungarian higher education, but this is the frame for international co-operation as well. In the US joining the SAP Alliance program is an option. In Europe under the frame of SAP support activities and other European programmes (SOCRATES, ERASMUS) there are plenty of opportunities.

\section{Internet Technology behind the BUES-SAP Excellence Center}

Fast and effective communication is an essential requirement in terms of the collaboration and the operation of the Excellence Center. Communication is of vital importance regarding to the integration as well. After evaluating the possibilities, we decided to use the Internet as the main communication channel of the Excellence Center. Advantages: fast, cheap, widely used in the academic world, flexible.

There are two mainstreams that can by identified:

- Providing access to the SAP R/3 educational demonstration system for the partner universities, participating in the project. The installed SAP system is physically located at the premises of the Excellence Center at BUES. 


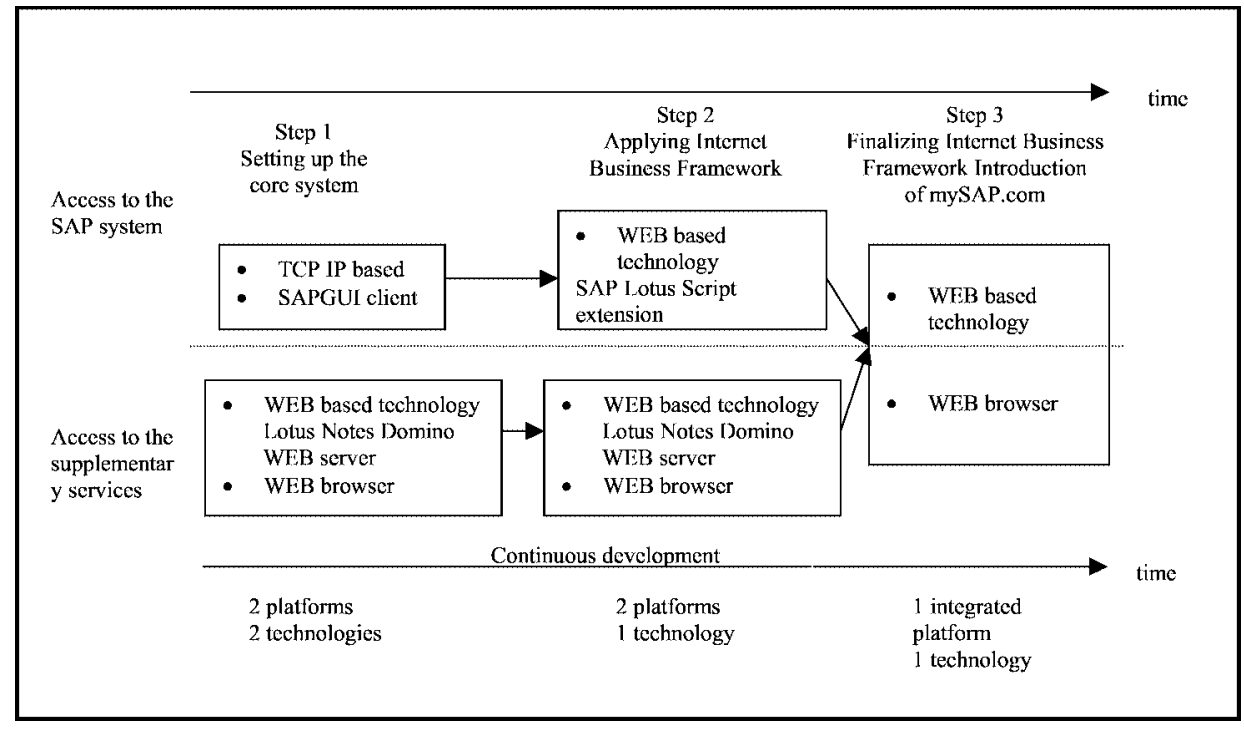

Fig. 4. Internet technology behind Excellence Center.

- Facilitating access to the various supplementary services supplied by the Center, even to those who may not be a partner in the project, but pay attention for certain fields of it. It also raises the question of differentiation of services and access levels.

The communication system, as the part of the whole Excellence Center, has to be developed in conjunction with the whole system. As the system gets more complex and more integrated, the communication subsystem has to become more complex and integrated as well. According to this, we set up a process for the development of the information system, just like we did for the Excellence Center Project. Steps and milestones are shown on Fig. 4.

\section{Step 1. Establishing the core systems}

1. Establishing the core systems involves the installation and the commission of a new SAP IDES system. SAP users are able to connect to the server over the Internet with an SAPGUI client, using the protocol TCP/IP.

2. Specification, design, implementation and installation of the web portal that supports the implementation of the supplementary services. The most important criteria, that the system should fulfil:

- Duplex communication. It has to be able to forward information from the Excellence Center towards our users, just like information should flow from the other direction. We also put emphasis on supporting the communication between our partners.

- Knowledge sharing. The system should be able to collect and share cumulated knowledge among the participants. 
Table 1

Short list of provided services

\begin{tabular}{l} 
Services \\
\hline Information delivery: general information, news, information on events - con- \\
ferences, courses, workshops \\
Teaching material exchange: curriculum, thesis topics, thesis, conference and \\
course materials, receiving submissions \\
Accessing archives: learning materials, thesis and curriculum archives, helpdesk \\
notes database \\
Maintaining mail lists, newsgroups and discussion databases \\
Helpdesk \\
Download software and help components
\end{tabular}

3. The range of the supported services and the access levels were defined. In addition, we also determined, which types of services are provided at the different access levels. The access levels are in accordance with the different roles, defined in the Excellence Center. The categories: normal, partner and "higher education club" access levels. Normal access level enables users to get access to the unsecured part of the web portal, where the Center's relevant, public information resides. Partner and higher education club level rights enable users to access the secured part of the web. Value added services and information are accessible only after an authorisation process. The short list of provided services is in Table 1.

The web relevant components were implemented in Lotus Notes, and also a Lotus Notes Domino Server backs the system.

In terms of the core systems, it can be clearly seen, that two different platforms exist, based on two different technologies. The goal of the process is to fully integrate the initial core systems into one complex, integrated system. The next two steps - what we head for - are the initiatives towards this direction. Nevertheless there are a few concerns, that are need to be taken into consideration. Technology we intend to use in Step 2 and Step 3, are among the newest developments, many of them is still changing. None or only a few installations of them exist thus their application may pose risks, that we certainly intend to take.

\section{Step 2. Application of Internet Business Framework}

As the first step of applying the Internet Business Framework, we are planning to place SAP onto web-based technology. Technically it requires an intermediary component (ITS - Internet Transaction Server or LSX - LotusScript eXtension) between the SAP and the web server. By the application of this technology SAP users will be able to access the functionality of the SAP system with a normal web browser. This way, we will be able to place both core system to web based technology and the use of SAPGUI clients would become unnecessary. However the platforms remain separated. 


\section{Step 3. Finalising the application of Internet Business Framework: Introduction of mySAP.com}

The introduction of mySAP.com workplace technology is the final step of the integration process. On the basis of this flexible and open infrastructure, mySAP.com provides an open collaborative environment of personalised solutions on demand. The new mySAP.com Workplace lets users enjoy easy, uniform and personalised Web access to both intranet and Internet, SAP and nonSAP specific applications and information from any place. It forms the basis of a new, common platform for both SAP specific functionality and BUES-SAP Excellence Center Services. In addition by the help of customisable, role-based user environments, we will be able to create uniform user environments for different educational purposes, where the most appropriate SAP functions could be collected, supplemented with the disposable additional materials, stored on the Excellence Center web site or anywhere else. All of these would be available on a common platform and just a click away.

\section{Conclusions}

Running an Excellence Center is a great challenge for a university. The technology of the Excellence Center logically follows the leading technology of software companies, however the business processes are significantly differing from a manufacturing or commercial, and even from a service company. Not mentioning the differences between the corporate/organisational culture. Therefore many cases, development issues should be handled in a unique way. Gaining and utilising these experiments keep us on track, and this the added value why the Excellence Center is a good investment.

\section{References}

Brown, A. (Ed.) (1992). Creating a Business-Based IT Strategy. Chapman \& Hall.

Claybrook, B. (1992). OLTP Online Transaction Processing. John Wiley \& Sons.

Davenport, T.H. (1998). Living with ERP. CIO Magazine (cio.com), December 1.

Davenport, T.H. (2000). Does ERP build a better business? CIO Magazine (cio.com), Feb. 15.

Davenport, T.H., and L. Prusak (1998). Working Knowledge: How Organiyations Manage What. Harvard Business School Press, They Know, Boston.

Dutta, S. et al. (1997). Designing management support systems. Communications of the ACM.

Gray, P., and J. Byun (2001). Customer Relationship Management. University of California, Irvine. www. crmassist.com/documents

Johnson, R.A. (2000). The ups and downs of object-oriented systems development. Communications of the ACM.

Koch, C. et al. (1999). The ABCs of ERP. CIO Magazine (cio.com), December 22.

Koory, J.L., and D.B. Medley (1987). Management Information Systems: Planning and Decision Making. South-Western Publishing Co.

Lederer, A.L. et al. (1998). Using web-based information systems to enhance competitiveness. Communications of the ACM, July.

McLeod, R.Jr. (1990). Management Information Systems. McMillan, New York.

Nonaka, I., and H. Takeuchi (1995). The Knowledge-Creating Company. Oxford University Press, New York. 
Palaniswamy, R., and T. Frank (2000). Enhancing manufacturing performance with ERP systems. Information Management Journal.

Parker, M.M., and R.J. Benson (1989). Enterprisewide information management: state-of-the-art strategic planning. Journal of Information Systems Management.

Peppers, D., and M. Rogers (1999). Enterprise One to One: Tools for Competing in the Interactive Age. Doubleday, Nem Zork.

Porter, M.E., and V.E. Millar (1985). How information gives you competitive advantage. Harvard Business Review.

Redman, T.C. (1998). The impact of poor data quality on the typical enterprise. Communications of the ACM.

Subrahmanyam, A. (1999). Nuts and Bolts of Transaction Processing. Www. subrahmanyam.com/articles/transactions/NutsAndBoltsofTP.html; www. sap.com

Turban, E. (1990). Decision Support and Expert Systems: Management Support Systems. Macmillan, New York, London.

K. Ternai, dr., senior lecture of the Department of Information Systems. She earned her university degree in Budapest, at the ELTE, MSc in mathematics and physics (1981). Later she got doctoral degree in computer science (1995). Her expertise: programming languages, OOP, Prolog, CLP, application software, ERP systems (SAP), system development, information management, intelligent systems. Foreign experiences: information mangement course University of Amsterdam (1992), PHARE/TEMPUS projects (19901997). Memberships: John von Neumann Society for Computing Sciences, professional experiences learnt in research and application projects. Participated and managed several SAP implementational and educational projects (from 1997). 


\section{Integruotuju sistemų vaidmuo švietimo integracijoje}

\section{Katalin TERNAI}

Informacinès visuomenės paradigma ir programa smarkiai įtakoja ir aukštajį mokslą. Smarkiai besikeičianti aplinka daro itaką ir mokymo turiniui, ir organizacijai. Su informatika susijusiose katedrose ir disciplinose pokyčiai yra itin ryškūs, tačiau informacinès technologijos gali iš esmès pakeisti ir tokias tradicines disciplinas kaip filosofija. Konservatyvaus akademinio pasaulio simptomas - organizacinè universitetų struktūra: labai hierarchiška, fragmentuotas žiniu (tai, kas vadinama švietimu) perdavimas. Kita vertus, tikroviškame pasaulyje susiduriame su visiškai priešingais reikalavimais: trūksta problemų sprendèjų ir profesionalų, gebančių integruotis bei ịsisavinti naujas žinias. Šios tendencijos informacinèje visuomeneje dar labiau stiprèja - tai galioja ir ekonominei, ir socialinei plotmėms. Paskutiniuosius dešimt metụ Vengrijos ūkis intensyviai vystėsi bei išgyveno dideliu pokyčiu periodą. Šio laikotarpio bendrieji pokyčiai ir informacinès visuomenès kūrimasis vyko drauge. Šiame straipsnyje supažindinama su mokymo plètros būdais aukštajame moksle kreipiant demesį ic procesų integraciją. 